\title{
PENERAPAN PSAK NO. 2 TENTANG LAPORAN ARUS KAS DALAM PENGAMBILAN KEPUTUSAN PADA PERUM BULOG DIRVE SULUT DAN GORONTALO
}

\section{APPLICATION FSAS NO. 2 ABOUT CASH FLOW STATEMENT IN DECISION MAKING ON BULOG DIVISION NORT SULAWESI AND GORONTALO}

\author{
Oleh: \\ Fanesa Isalia Minanda Syaefudin'1 \\ Jenny Morasa ${ }^{2}$ \\ Stanly W. Alexander ${ }^{3}$ \\ Fakultas Ekonomi dan Bisnis, Jurusan Akuntansi \\ Universitas Sam Ratulangi
}

Email: 1 fanesasyaefudin@yahoo.com

\begin{abstract}
Abstrak: Laporan Keuangan dalam perusahaan merupakan alat pertimbangan dalam pengambilan keputusan sehingga, komponen-komponen dalam Laporan Keuangan haruslah benar dan tepat. Dalam pengambilan keputusan perusahaan, sebaiknya menggunakan Laporan Arus Kas karena terkadang Laporan Laba Rugi dan Neraca tidak menampilkan keadaan sesungguhnya dari keuangan perusahaan.Tujuan penelitian ini untuk mengetahui penerapkan laporan arus kas berdasarkan PSAK No. 2 dalam pengambilan keputusan perusahaan.Jenis penelitian adalah Deskriptif Kuantitatif. Hasil penelitian menunjukkan, kas bersih yang diperoleh perusahaan selama tahun berjalan mengalami penurunan dibandingkan tahun sebelumnya. Penelitian ini menggunakan analisis rasio dalam pengambilan keputusan perusahaan.Rasio Arus Kas Operasi Terhadap Total Kewajiban dapat dijadikan dasar pengambilan keputusan perusahaan dalam melunasi kewajiban totalnya selama satu tahun operasinya.Rasio Arus Kas Terhadap Kewajiban Lancar dapat dijadikan dasar pengambilan keputusan perusahaan saat mengukur kemampuan perusahaan dalam membayar hutang lancar berdasarkan arus kas operasi bersih.Rasio Arus Kas Terhadap Penjualan perusaaan mengukur kemampuan perusahaan dalam memperoleh kas dari penjualan.Sebaiknyapimpinan perum Bulog khususnya bagian keuangan perlu menerapkan Laporan Arus Kas sebagai dasar analisisnya, sehingga perusahaan dapat mengetahui keadaan keuangannya dan dapat dijadikan dasar pengambilan keputusan perusahaan.
\end{abstract}

Kata Kunci: penerapan, arus kas, pengambilan keputusan

\begin{abstract}
Abstact: In the company's Financial Statements is a means of consideration in decision making so that, componentsin the financial statements must betrue and correct. In thedecision making companies should use the cash Flow Statement because sometimes the income and balance sheet does not show the real state of corporate finance. The purposeof this study to determine the application of the Cash Flow Statement in accordance with SFAS No. 2 in corporate decision. This type of research is quantitative descriptive. The results showed, net cash provided by the company during the year has decreased compared to the previous year. This study uses the ratio analysisin corporate decision making. The Ratio of Operating Cash Flow to Total Liabilities can be used as basis for decision making in the company repay its total Liability for one year of operation. The Ratio of Cash Flow to Current Liabilities can be used as the basis of the decision making companies when measuring the company's ability to pay Current Liabilities by Net Operating Cash Flow. The Ratio of Cash Flow to Sales companies measure the company's ability to measure the company's ability to obtain cash from to sale. Leaders should Perum Bulog particularly the finance department needs to implement the Cash Flow Statement as the basis of its analysis so that can know the financial situation and can be used as a basis for decision making of the company.
\end{abstract}

Keywords: implementation, cash flow, decision making 


\section{PENDAHULUAN}

\section{Latar Belakang}

Kemajuan teknologi yang semakin pesat seiring perkembangan zaman membuat dunia bisnis dan pelaku-pelaku bisnis di zaman ini bergerak lebih aktif.Mampu membaca setiap situasi yang terjadi dan melihat peluang-peluang yang muncul serta cepat dalam bertindak guna perluasan usaha. Jika tidak, maka akan membuat kertertinggalan dalam bisnis itu sendiri.

Akuntansi memainkan peranan yang sangat penting dalam masyarakat.Sebagai cabang dari ilmu ekonomi, akuntansi menyediakan informasi mengenai perusahaan dan transaksinya untuk memfasilitasi keputusan alokasi sumber daya oleh para pengguna informasi tersebut.Jika informasi yang dilaporkan dapat diandalkan dan bermanfaat, maka sumber daya yang terbatas itu dapat dialokasikan secara optimal, dan sebaliknya alokasi sumber daya menjadi kurang optimal jika informasi kurang andal dan tidak bermanfaat.Akuntansi disebut sebagai bahasa bisnis karena merupakan suatu alat untuk menyampaikan informasi keuangan kepada pihak-pihak yang memerlukannya.Untuk menyampaikan informasi-informasi tersebut, maka digunakanlah laporan akuntansi atau yang dikenal sebagai laporan keuangan.Laporan keuangan adalah catatan informasi keuangan suatu perusahaan pada suatu periode akuntansi yang dapat digunakan untuk menggambarkan kinerja perusahaan tersebut.

Bagi suatu perusahaan, Laporan Keuangan merupakan media paling penting untuk menilai prsetasi dan kondisi ekonomi perusahaan. Seorang manajer tidak akan mampu melakukan pengamatan langsung ke suatu perusahaan. Dan seandainya dilakukan, ia pun tidak akan dapat mengetahui banyak tentang situasi perusahaan. Oleh karena itu, yang paling penting adalah media laporan keuangan. Laporan keuangan inilah yang menjadi bahan sarana informasi bagi manajer dalam proses pengambilan keputusan. Laporan keuangan yang menjadi bahan pertimbangan manajer dalam pengambilan keputusan, diperlukan analisis yang tepat dalam suatu laporan keuangan.Menganalisis laporan keuangan berarti menggali lebih banyak informasi yang terdapat dalam suatu laporan keuangan.Sebagaimana diketahui laporan keuangan adalah media informasi yang merangkum semua aktivitas perusahaan. Jika informasi ini disajikan dengan sesuai, maka dapat membawa suatu perusahaan di situasi yang akan sangat menguntungkan. Laporan keuangan dapat mengambarkan posisi keuangan perusahaan, hasil usaha perusahaan dalam suatu periode, dan arus dana perusahaan dalam periode tertentu.

Laporan arus kas disajikan untuk melengkapi kesenjangan informasi yang tidak termuat dalam informasi lain. Laporan arus kas memainkan peranan komplementer bagi neraca dan laporan laba rugi dalam penjabaran secara lengkap mengenai asset dan stuktur keuangan (kewajiban dan ekuitas pemilik) perusahaan serta bagaimana asset, kewajiban, dan ekuitas tersebut berubah dalam periode tertentu.

Salah satu alasan dilakukannya penerapan terhadap laporan arus kas adalah sebagai salah satu alat bantu dalam pengambilan keputusan. Dimana dalam laporan arus kas dapat dilihat laporan kas masuk dan keluar selama periode tertentu.Selain itu, informasi yang terdapat pada laporan arus kas lebih mencerminkan posisi kas yang sebenarnya yang ada di perusahaan.Oleh karena itu, dalam pengambilan keputusan suatu perusahaan sangatlah tepat bila digunakan informasi yang disajikan dalam laporan arus kas.

\section{Tujuan Penelitian}

Tujuan penelitian ini untuk mengetahui penerapan Laporan Arus Kas pada suatu perusahaan yang didasarkan pada Pernyataan Standar Akuntansi Keuangan Nomor 2 dalam pengambilan keputusan pada Perum Bulog Divre Sulut dan Gorontalo.

\section{TINJAUAN PUSTAKA}

\section{Konsep Akuntansi}

Robert, Patricia, dan Daniel (2007:4), mengungkapkan bahwa akuntansi merupakan sebuah sistem yang mengumpulkan dan memroses (menganalisis, menghitung, dan mencatat) informasi keuangan mengenai sebuah organisasi dan melaporkan informasi keuangan mengenai sebuah organisasi dan melaporkan informasi tersebut kepada pengambil keputusan. Warsono (2009:3), mengungkapkan bahwa akuntansi adalah proses sistematis untuk mengelolah transaksi menjadi informasi keuangan yang bermanfaat bagi para penggunanya. Akuntansi professional bekerja dalam banyak peran serta lingkungan yang berbeda.Oleh karena itu, dalam prakteknya 
akuntansi dapat dibedakan dengan skope atau ruang lingkup yang tercakup di dalamnya yang meliputi akuntansi public yang bekerja secara independen serta akuntan intern perusahaan.

\section{Laporan Keuangan}

Informasi akuntansi keuangan menunjukkan kondisi keuangan dan hasil usaha suatu perusahaan yang digunakan oleh para pemakainya sesuai dengan kepentingan masing-masing. Laporan akuntansi disiapkan untuk memberikan informasi yang berguna bagi para pemakai laporan, terutama sebagai dasar pertimbangan dalam proses pengambilan keputusan. Laporan akuntansi ini dinamakan laporan keuangan. Laporan keuangan mampu memberikan banyak informasi yang dapat dipakai oleh para pengguna dalam membuat keputusan ekonomis perusahaan. Laporan keuangan adalah laporan tertulis yang memberikan infromasi kuantitatif tentang posisi keuangan dan perubahan-perubahannya, serta hasil yang dicapai selama periode tertentu.Laporan keuangan memberikan gambaran tentang bagaimana susunan kekayaan yang dimiliki perusahaan dan sumber-sumber kekayaan itu didapat. PSAK No. 1 mengatur bahwa laporan keuangan lengkap harus mencakup komponenkomponen berikut:Laporan posisi keuangan (neraca) pada akhir periode, Laporan laba rugi komprehensif, Laporan perubahan ekuitas, Laporan arus kas dan Kebijakan akuntansi serta catatan atas laporan keuangan.

\section{Tujuan Laporan Keuangan}

Hery (2012:4), mengungkapkan bahwa tujuan khusus laporan keuangan adalah menyajikan secara wajar dan sesuai dengan prinsip akuntansi yang berlaku umum mengenai posisi keuangan, hasil usaha, dan perubahan lain dalam posisi keuangan. Standar akuntansi keuangan (SAK) dijelaskan tentang tujuan laporan keuangan yang isinya: "tujuan laporan keuangan adalah menyediakan informasi yang menyangkut posisi keuangan, kinerja, serta perubahan posisi keuangan suatu perusahaan yang bermanfaat bagi sejumlah besar pemakai dalam pengambilan keputusan ekonomi.

\section{Laporan Arus Kas}

Hery (2012:9), mengungkapkan bahwa laporan arus kas (statement of cash flows) adalah sebuah laporan yang menggambarkan aus kas masuk dan arus kas keluar secara terperinci dari masing-masing aktivitas, yaitu mulai dari aktivitas operasi, aktivitas investasi, sampai pada aktivitas pendanaan/ pembiayaan untuk satu periode tertentu.Laporan arus kas menunjukkan besarnya kenaikkan/ penurunan bersih kas dari seluruh aktivitas selama periode berjalan serta saldo kas yang dimiliki perusahaan sampai dengan akhir periode. Skousen (2001:8), bahwa sebagai salah satu bagian dari laporan keuangan lainnya, laporan arus kas pada dasarnya adalah sebuah laporan yang melaporkan, untuk interval tertentu, jumlah kas yang ditimbulkan dikonsumsikan oleh suatu perusahaan melalui tipe - tipe aktivitas berikut, yaitu aktivitas operasi, aktivitas investasi dan keuangan.Honrngren (2007:148) laporan arus kas melaporkan arus kas penerimaan dan pengeluaran kas selama suatu periode.Laporan ini menunjukkan dari mana asal kas dan bagaimana kas dibelanjakan.Laporan ini menjelaskan sebab-sebab perubahan dalam kas selama suatu periode tertentu.

\section{Tujuan dan Manfaat Laporan Arus Kas}

PSAK No. 2 mengungkapkan bahwa Laporan Arus Kas dapat memberikan informasi yang memungkinkan para pengguna untuk mengevaluasi perubahan dalam asset bersih entitas. Informasi Arus Kas berguna untuk menilai kemampuan entitas dalam menghasilkan kas dan setara kas dan memungkinkan para pengguna mengembangkan model untuk menilai dan membandingkan nilai sekarang dari arus kas masa depan dari berbagai entitas.Bambang (2014:41), mengungkapkan bahwa manfaat informasi arus kas setidaknya ada tiga. Pertama, sebagai indokator jumlah arus kas dimasa yang akan datang dan menilai kecermatan taksiran arus kas yang telah dibuat sebelumnya. Kedua, laporan arus kas juga menjadi alat pertanggungjawaban arus kas masuk dan arus kas keluarselama periode pelaporan.Ketiga, laporan arus kas memberikan informasi yang bermanfaat bagi pengguna laporan dalam mengevaluasi perubahan kekayaan bersih, ekuitas, dan struktur keuangan perusahaan termasuk likuiditas dan solvabilitas.

\section{Laporan Arus Kas Dalam Pengambilan Keputusan}

Wahjono (2010:241) mengungkapkan bahwa proses pengambilan keputusan strategis adalah proses yang terjadi di tingkat organisasi yang melibatkan serangkaian aktivitas organisasi dalam formulasi misi starategis dan tujuan. Proses ini melibatkan proses analisis, perencanaan, pengambilan aspek seperti budaya organisasi, system nilai, dan visi perusahaan. Pengambilan keputusan dapat dianggap sebagai suatu hasil atau keluaran dari prosesmental atau kognitif yang membawa pada pemilihan suatu jalur tindakan di antara beberapa alternatif yang tersedia. Setiap proses pengambilan keputusan selalu menghasilkan satu pilihan final. Keputusan 
dibuat untuk mencapai tujuan melalui pelaksanaan atau tindakan. Informasi yang terdapat dalam laporan arus kas dapat memberikan gambaran untuk memprediksi kemampuan perusahaan dalam melunasi kewajiban, melakukan investasi, menghasilkan laba dan arus kas dimasa yang akan datang. Hal ini karena dalam laporan arus kas terlihat penggunaan kas yang ada dalam perusahaan dan juga arus kas selama periode tertentu.Dalam memprediksi kemampuan perusahaan untuk menghasilkan laba berdasarkan Laporan Arus Kas, perusahaan dapat menggunakan analisis Rasio Arus Kas Terhadap Penjualan. Untuk memprediksi kemampuan perusahaan dalam melunasi kewajibannya dapat dilakukan dengan analisis beberapa rasio yang masih berkaitan dengan arus kas yaitu rasio arus kas operasi terhadap total kewajiban dan rasio arus kas operasi terhadap kewajiban lancar.

\section{Penelitian Terdahulu}

Sutarti (2012) dengan judul Penyajian laporan arus kas menurut PSAK 2 guna mendukung pengambilan keputusan investasi pada PT. Pan Brothers Tbk. Tujuannya untuk mengetahui penyajian laporan arus kas yang sesuai dengan PSAK serta peran laporan arus kas dalam pengambilan keputusan pada PT. Pan Brothers, Tbk. Metode yang digunakan adalah deskriptif kuantitatif. Hasil penelitian menunjukkan bahwa pada PT. Pan Brothers, Tbk telah menyusun laporan arus kas yang sesuai dengan PSAK 2. Laporan arus kas yang disusun digunakan oleh manajemen sebagai pendukung dalam pengambilan keputusan investasi.

James (2013) dengan judul Analisis laporan arus kas sebagai alat ukur menilai kinerja pada PT. Pegadaian (Persero) Cabang Manado Timur. Tujuannya untuk mengetahui penggunaan Laporan arus kas sebagai alat ukur menilai kinerja keuangan menilai kinerja keuangan pada PT. Pegadaian (Persero) Cabang Manado Timur. Metode yang digunakan adalah deskriptif kuantitatif. Hasil penelitian PT. Pegadaian (Persero) Cabang Manado Timur merupakan perusahaan yang bergerak dalam bidang pembiayaan gadai. Aktivitas perusahaan dalam hal ini adalah baik karena sumber kas yang terbesar berasal dari aktivitas operasi yaitu laba bersih yang merupakan sumber kas utama bagi perusahaan. Pembelian Pembangkit Listrik dan Pemeliharaanya berpotensi mengurangi harta perusahaan, serta jumlah kas yang menganggur pada perusahaan selama 2 tahun

\section{METODE PENELITIAN}

\section{Jenis Penelitian}

Jenis penelitian yang digunakan adalah penelitian deskriptif kuantitatif.Penelitian deskriptif adalah penelitian yang ingin mencari jawab secara mendasar tentang sebab akibat dengan menganalisis faktor-faktor terjadinya atau munculnya fenomena tertentu, dimana peneliti melakukan penelitian langsung ke objek penelitian kemudian mengumpulkan data-data dan menganalisis data-data tersebut berdasarkan fakto-faktor yang sudah ditentukan.Dalam penelitian ini digunakan analisis rasio-rasio yang berhubungan dengan laporan arus kas dalam pengambilan keputusan perusahaan.Rasio-rasio yang digunakan adalah rasio arus kas operasi terhadap total kewajiban, rasio arus kasterhadap kewajiban lancar, dan rasio arus kas terhadap penjualan.

\section{Tempat dan Waktu Penelitian}

Penelitian ini dilakukan di Perum Bulog Divre Sulut dan Gorontalo yang beralamat di jalan Diponegoro nomor 8-9 Manado.Adapun waktu penelitian dimulai dari bulan Maret tahun 2015.

\section{Prosedur Penelitian}

Tahap penelitian yang berhubungan dengan masalah yang diteliti, tahapan-tahapan tersebut sebagai berikut.

1. Mengsurvei objek penelitian, yaitu turun langsung ke lapangan untuk mengamati kejadian-kejadian yang terjadi dalam tempat penelitian. Dalam penelitian ini tempat yang akan dijadikan objek penelitian adalah Perum Bulog Divre Sulut dan Gorontalo.

2. Mengumpulan data-data atau informasi yang diperlukan. Dalam pengumpulan data ini, dapat dilakukan dengan cara mewawancarai karwayan/ staff perusahaan. Selain itu dalam penelitian ini juga memperoleh data melalui media internet yaitu www.bulog.co.id.

3. Menganalisis data tersebut dan dimasukkan dalam laporan.

4. Melaporkan hasil analisis yang sudah dituangkan dalam satu laporan.

\section{Definisi Operasional dan Pengukuran Variabel}


Definisi operasional adalah definisi yang diberikan kepada suatu variable atau konstrak dengan cara memberikan arti atau menspesifikasi kegiatanataupun memberikan suatu operasional yang diperlukan untuk mengukur konstrak atau variabel tersebut. Definisi operasional didasarkan atas sifat-sifat variabel yang diamati.Definisi operasional mencakup hal-hal penting dalam penelitian yang memerlukan penjelasan. Dalam penelitian ini, variable yang digunakan adalah:

a. Variabel Terikat (Y)

Variabel terikat dalam penelitian ini adalah pengambilan keputusan.Pengambil keputusan dapat lebih tinggi.Istilah fakta perlu dikaitkan dengan istilah data dan informasi.Kumpulan fakta yang telah dikelompokkan secara sistematis dinamakan data.Sedangkan informasi adalah hasil pengolahan dari data.Dengan demikinan, data harus diolah lebih dulu menjadi informasi yang kemudian dijadikan dasar pengambilan keputusan.

b. Variabel Bebas (X)

Dalam penelitian ini memiliki satu variable bebas (X1) adalah Penerapan PSAK No. 2 tentang Laporan Arus Kas. Penerapan Laporan arus kas oleh manajemen untuk mengevaluasi kegiatan operasional yang telah berlangsung, dan merencanakan aktivitas investasi dan pembiayaan dimasa yang akan datang. Laporan Arus Kas dapat digunakan untuk menilai kemungkinan arus kas dimasa yang akan datang, untuk memprediksi kemungkinan perusahaan dalam menghasilkan laba dan melunasi kewajibannya. Jadi, laporan ini sangat diperlukan seorang manajer perusahaan sebelum mengambil keputusan yang akan berdampak bagi perusahaan dimasa yang akan datang.

\section{HASIL PENELITIAN DAN PEMBAHASAN}

\section{Hasil Penelitian}

Bulog adalah perusahaan umum milik negara yang bergerak di bidang logistik pangan. Ruang lingkup bisnis perusahaan meliputi usaha logistik/pergudangan, survei dan pemberantasan hama, penyediaan karung plastik, usaha angkutan, perdagangan komoditi pangan dan usaha eceran. Sebagai perusahaan yang tetap mengemban tugas publik dari pemerintah, Bulog tetap melakukan kegiatan menjaga Harga Dasar Pembelian untuk gabah, stabilisasi harga khususnya harga pokok, menyalurkan beras untuk orang miskin (Raskin) dan pengelolaan stok pangan.

Visi Perusahaan yaitu: Menjadi perusahaan yang unggul dalam mewujudkan kedaulatan pangan. Visi ini juga mencerminkan misi yang diamanatkan oleh Pemerintah, khususnya berkaitan dengan keberhasilan dan ketahanan pangan nasional. Posisi Bulog sebagai lembaga pangan yang handal mencakup pemantapan kesejahteraan pangan nasional, professional dan kompetitif dalam bidang usaha pangan serta senantiasa memiliki rasa dan nilai kepekaan atas tanggungjawabnya bagi kepentingan masyarakat serta taat dan menjunjungtinggi nilai-nilai etika dalam melaksanakan bisnis

Perum Bulog memiliki tiga misi yaitu:

1. Memberikan pelayanan prima kepada masyarakat dan pemangku kepentingan lainnya untuk memenuhi kebutuhan pangan pokok.

2. Mencapai pertumbuhan usaha yang berkelanjutan.

3. Menerapkan tata kelola perusahaan yang baik.

Misi yang berfokus pada kompentendesian tujuan/ makna utama (one common purpose) dari keberadaan perum Bulog diharapkan dapat mencerminkan keyakinan atau nilai organisasi serta memberikan makna pada setiap karyawan Bulog sehingga mampu menyatukan organisasi dan membangun komitmen bersama.

\section{Kebijakan Akuntansi Perusahaan}

Laporan keuangan yang disusun oleh Perum Bulog dibuat berdasarkan Pernyataan Standar Akuntansi Keuangan (PSAK) yang dikembangkan dalam aplikasi Sistem Informasi Akuntansi Bulog (SIAB) untuk kantor pusat, dengan melakukan penggabungan antara database Kantor Pusat dengan database Divre Selindo, sehingga seluruh transaksi tergabung dalam satu database. Laporan Keuangan Perusahaan Umum (Perum) Bulog disusun mengacu kepada SAK yang penerapannya dituangkan dalam Kebijakan Akuntansi Bulog (KAB) sesuai Keputusan Direksi Perum Bulog nomor: Kep 257/Dir/12/2003 tanggal 24 Desember 2003.

\section{Dasar Pengambilan Keputusan Perusahaan}


Dasar pengambilan keputusan yang di terapkan oleh Perusahaan Umum Bulog adalah menganalisis laporan keuangan secara keseluruhan.Berdasarkan laporan keuangan tersebut maka ditariklah kesimpulan sebagai dasar pertimbangan pengambilan keputusan perusahaan pada masa yang akan datang. Karena perusahaan belum menerapkan Laporan Arus Kas dalam komponen laporan keuangannya, maka dasar pengambilan keputusan perusahaan belum melibatkan Laporan Arus Kas.

\section{Arus Kas dari Aktivitas Operasi}

Penerapan arus kas berdasarkan arus kas dari aktivitas operasi Perum Bulog melibatkan penerimaan kas dari pelanggan, pembayaran kepada pemasok, pembayaran beban usaha, dan pembayaran pajak penghasilan.

1. Penerimaan kas dari pelanggan dihitung sebagai berikut:

$$
\begin{array}{ll}
\text { Penjualan } & =R p . x x x \\
\text { Dikurangi kenaikan piutang usaha } & =\underline{R p . x x x} \\
& =R p . x x x
\end{array}
$$

2. Pemabayaran kas kepada pemasok dan karyawan dihitung sebagai berikut:
Harga pokok penjualan
$=$ Rp. $x x x$
Ditambah kenaikan persediaan
$=\underline{\text { Rp. } x x x}$
Pembelian
$=$ Rp. $x x x$
Ditambah pengurangan hutang usaha
$=\underline{\text { Rp. } x x x}$
Pembayaran kepada pemasok
$=$ Rp. $x x x$

3. Pembayaran beban usaha dihitung sebagai berikut:

Beban operasi

$=$ Rp. $x x x$

Ditambah kenaikan pembayaran dimuka

$=\underline{\mathrm{Rp}} \cdot \mathrm{xxx}$

Pembayaran beban usaha

$$
=\mathrm{Rp} \cdot \mathrm{xxx}
$$

4. Pembayaran pajak penghasilan dihitung sebagai berikut:
Tagihan pajak
Ditambah penurunan hutang pajak

$$
\begin{aligned}
& =\text { Rp. } x x x \\
& =\text { Rp. } x x x \\
& =\text { Rp. } x x x
\end{aligned}
$$

Arus Kas dari Aktivitas Investasi

Penerapan arus kas berdasarkan arus kas dari aktivitas investasi melibatkan uang muka yang diberikan perusahaan, biaya yang ditanggunghkan, dan pembelian aktiva tetap.

\begin{tabular}{|c|c|}
\hline $\begin{array}{l}\text { Laporan Arus Kas } \\
\text { Perusahaan Umum Bulog }\end{array}$ & \\
\hline ARUS KAS DARI AKTIVITAS OPERASI & \\
\hline Penerimaan dari pelanggan & Rp. $x x x$ \\
\hline Pembayaran kepada pemasok & Rp. xxx \\
\hline Pembayaran beban usaha & Rp. $x x x$ \\
\hline Pembayaran pajak penghasilan & $\underline{\mathrm{Rp}} . \mathrm{xxx}$ \\
\hline $\begin{array}{l}\text { Kas Bersih Yang Di Peroleh Dari Aktivitas Operasi } \\
\text { ARUS KAS DARI AKTIVITAS INVESTASI }\end{array}$ & $\overline{\text { Rp. } \mathrm{xxx}}$ \\
\hline Penambahan Uang Muka & Rp. Xxx \\
\hline Biaya ditangguhkan & Rp. XXX \\
\hline Pembelian Aktiva TetapRp. xxx & \\
\hline $\begin{array}{l}\text { Kas Bersih Yang Digunakan Untuk Aktivitas Investasi } \\
\text { ARUS KAS DARI AKTIVITAS PENDANAAN }\end{array}$ & Rp. $\mathbf{x x x}$ \\
\hline
\end{tabular}

Arus Kas dari Aktivitas Pendanaan

Penerapan arus kas berdasarkan arus kas dari aktivitas pendanaan melibatkan penerimaan pinjaman bank jangka pendek,

Pinjaman bank jangka pendek dihitung sebagai berikut:

$$
\begin{array}{ll}
\text { Hutang Bank tahun } 2014 \text { (akhir) } & =\mathrm{Rp} . \mathrm{xxx} \\
\text { Hutang Bank tahun } 2013 \text { (akhir) } & =\underline{\mathrm{Rp} . \mathrm{xxx}}
\end{array}
$$

Tabel 1 


\begin{tabular}{|c|c|}
\hline Penerimaan pinjaman bank jangka pendek & Rp. $x x x$ \\
\hline Kas Bersih Yang Digunakan Untuk Aktivitas Pendanaan & Rp. $x x x$ \\
\hline Penurunan Bersih Kas Dan Setara Kas & Rp. $x x x$ \\
\hline Kas dan Setara Kas Awal Tahun & $\underline{\text { Rp. } x x x}$ \\
\hline Kas dan Setara Kas Akhir Tahun & $\underline{\text { Rp. } x x x}$ \\
\hline
\end{tabular}

Sumber: Hasil Olahan Data

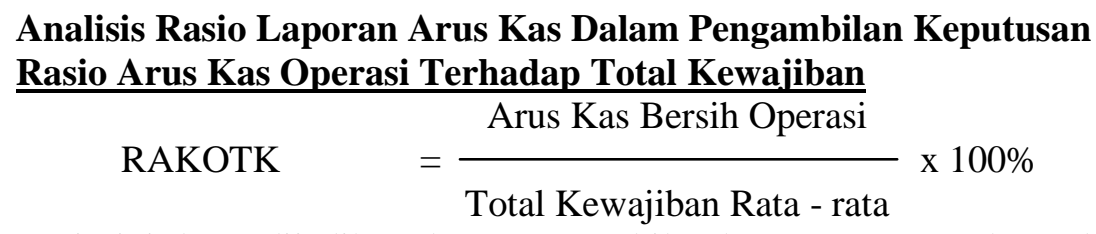

Rasio ini dapat dijadikan dasar pengambilan keputusan perusahaan dalam melunasi kewajiban totalnya selama satu tahun operasinya. Semakin tinggi rasio ini, semakin kecil kemungkinan perusahaan akan mengalami kesulitan dalam memenuhi kewajibannya pada saat jatuh tempo.

Rasio Arus Kas Terhadap Kewajban Lancar

$$
\text { RAKOKL }=\frac{\text { Arus Kas Bersih Operasi }}{\text { Kewjiban Lancar }} \times 100 \%
$$

Rasio ini, dapat dijadikan dasar pengambilan keputusan perusahaan saat mengukur kemampuan perusahaan dalam membayar hutang lancar berdasarkan arus kas operasi bersih.Semakin tinggi rasio ini, semakin besar kemampuan perusahaan dalam menutup hutang lancar dari arus kas operasi.

$\underline{\text { Rasio Arus Kas Terhadap Penjualan }}$

$$
\text { Cash Flow to Sales }=\frac{\text { Arus Kas Operasi }}{\text { Penjualan }} \times 100 \%
$$

Rasio ini, dapat dijadikan dasar pengambilan keputusan perusahaan saat mengukur kemampuan perusahaan dalam memperoleh kas dari penjualan.Semakin tinggi rasio ini, semakin besar kas yang diperoleh dari penjualan serta semakin efiien kegiatan operasi atau penjualan perusahaan.

\section{Pembahasan}

Penerapan Laporan Arus Kas bagi suatu perusahaan sangatlah penting karena Laporan Arus Kas tersaji pengelolaan arus kas keluar dan arus kas masuk pada suatu perusahaan selama periode tertentu.Laporan arus kas biasanya disajikan dalam satu halaman laporan. Tidak ada bentuk atau format baku yang harus diikuti oleh semua perusahaan dalam penyajian laporan arus kasnya. Dengan demikian, sejauh mana perincian yang disajikan tergantung kebutuhan perusahaan.Sebagai catatan penting yang harus disediakan adalah jika laporan arus kas harus bisa menjadi alat yang efektif untuk menjawab berbagai pertanyaan sehubungan dengan aliran kas perusahaan.

Laporan arus kas memberikan informasi mengenai arus kas masuk dan arus kas keluar dan juga setara kas (equivalent cash).Laporan jenis ini dianggap lebih informative dari pada laporan perubahan posisi keuangan karena dapat memberikan informasi tentang arus kas historis suatu perusahaan sehingga dapat diketahui arus kas masuk dan arus kas keluar pada masa lalu.Dalam PSAK No. 2 Arus kas adalah arus masuk atau arus keluar kas atau setara kas.Laporan arus kas harus melaporkan arus kas selama periode tertentu dan diklasifikasi menurut aktivitas operasi, investasi, dan pendanaan. Entitas penyajian Arus Kas dari aktivitas operasi, investasi, dan pendanaan dengan cara yang paling sesuai dengan bisnis entitas tersebut. Informasi yang terdapat dalam laporan arus kas dapat memberikan gambaran untuk memprediksi kemampuan perusahaan dalam melunasi kewajiban, melakukan investasi, menghasilkan laba dan arus kas dimasa yang akan datang. Hal ini karena dalam laporan arus kas terlihat penggunaan kas yang ada dalam perusahaan dan juga arus kas selama periode tertentu.

Dalam penelitian ini digunakan analisis rasio arus kas sebagai dasar pengambilan keputusan perusahaan yaitu: rasio arus kas operasi terhadap total kewajiban dapat dijadikan dasar pengambilan keputusan perusahaan dalam melunasi kewajiban totalnya selama satu tahun operasinya, rasio arus kas terhadap kewajiban lancar dapat dijadikan dasar pengambilan keputusan perusahaan saat mengukur kemampuan perusahaan dalam membayar hutang lancar berdasarkan arus kas operasi bersih, dan rasio arus kas terhadap penjualan dapat 
dijadikan dasar pengambilan keputusan perusahaan saat mengukur kemampuan perusahaan dalam memperoleh kas dari penjualan.

Laporan arus kas dapat digunakan oleh manajemen untuk mengevaluasi kegiatan operasional yang telah berlangsung, dan merencanakan aktivitas investasi dan pembiayaan dimasa yang akan datang. Dengan membandingkan laporan arus kas selama beberapa periode, dapat digunakan untuk menilai kemungkinan arus kas dimasa yang akan datang dan juga untuk memprediksi kemungkinan perusahaan dalam menghasilkan laba. Jadi, laporan ini sangat diperlukan seorang manajer perusahaan sebelum mengambil keputusan yang akanberdampak bagi perusahaan dimasa yang akan datang.

Penelitian ini didukung penelitian terdahulu yang dilakukan oleh James (2013) yaitu analisis laporan arus kas sebagai alat ukur menilai kinerja pada PT. Pegadaian (Persero) Cabang Manado Timur. Persamaan penelitian tersebut dengan penelitian kali ini adalah sama-sama menggunakan perhitungan rasio arus kas, sedangkan perbedaannya pada penelitian tersebut perusahaan sudah menggunakan laporan arus kas, sedangkan pada penelitian kali ini baru menerapkan arus kas.

\section{PENUTUP}

\section{Kesimpulan}

Kesimpulan dari penelitian ini adalah:

1. Dalam PSAK No. 2 salah satu komponen dalam Laporan Keuangan adalah Laporan Arus Kas.PSAK No. 2 menjelaskan bahwa dalam menerapkan Laporan Arus Kas perlu diketahui komponen - komponen penting yang terdapat dalam Laporan Arus Kas, yaitu Arus Kas dari Aktivitas Operasi, Arus Kas dari Aktivitas Investasi, dan Arus Kas dari Aktivitas Pendanaan. Melalui ketiga komponen utama dalam arus kas ini, perusahaan dapat melihat lebih rinci mengenai pengeluaran-pengeluaran dan pendapatan-pendapatan perusahaan selama periode aktivitas tertentu pada perusahaan.

2. Penerapan Laporan arus kas oleh manajemen untuk mengevaluasi kegiatan operasional yang telah berlangsung, dan merencanakan aktivitas investasi dan pembiayaan dimasa yang akan datang. Laporan Arus Kas dapat digunakan untuk menilai kemungkinan arus kas dimasa yang akan datang dan juga untuk memprediksi kemungkinan perusahaan dalam menghasilkan laba. Jadi, laporan ini sangat diperlukan seorang manajer perusahaan sebelum mengambil keputusan yang akan berdampak bagi perusahaan dimasa yang akan datang.

\section{Saran}

Saran penelitian ini adalah:

1. Pimpinan Perum Bulog khususnya bagian keuangan perlu menerapkan Laporan Arus Kas untuk perusahaan sebagai dasar analisisnya. Hal ini dilihat karena laporan laba rugi dan neraca terkadang tidak menampilkan keadaan sesungguhnya dari keuangan perusahaan.

2. Rasio-rasio yang berhubungan dengan arus kas, ada baiknya dilakukan analisis secara terus-menerus agar perusahaan dapat mengetahui keadaan keuangannya dan dapat dijadikan dasar pengambilan keputusan yang nantinya akan berdampak bagi kemajuan perusahaan di masa yang akan datang.

\section{DAFTAR PUSTAKA}

Horngren 2007, Akuntansi - Jilid Satu Edisi Kesepuluh. Penerbit Erlangga, Jakarta.

Hery 2012, Analisis Laporan Keuangan- Edisi Pertama. Penerbit PT. Bumi Aksara, Jakarta

Ikatan Akuntan Indonesia.PSAK No. 1 Tentang Penyusunan Laporan Keuangan - edisi revisi 2013. Penerbit Dewan Standar Akuntansi Keuangan.

Ikatan Akuntan Indonesia.PSAK No. 2 Tentang Laporan Arus Kas-edisi revisi 2013. Penerbit Dewan Standar Akuntansi Keuangan. 
Indrawan Rully dan Yaniawati Poppy (2014), Metodologi PenelitianKuantitatif, Kualitatif dan Campuran Untuk Manajemen, Pembangunan dan Pendidikan. Penerbit PT. Refika Aditama, Bandung.

Kaunang, James M. 2013. Analisis Laporan Arus Kas Sebagai Alat Ukur Menilai Kinerja Pada PT. Pegadaian (Persero) Cabang Manado Timur. Universitas Sam Ratulangi. Manado. Jurnal Emba. Vol. 1. No. 3. (2013) http://download.portalgaruda.org/article.php?article=108758\&val=1025. Diakses Maret, 15, 2015. Hal.455-464.

Robert, Patricia, dan Daniel 2007, Akuntansi Keuangan.-edisi kelima. Penerbit Andi, Yogyakarta

Sutarti. 2012. Penyajian Laporan Arus Kas Menurut PSAK 2 Guna Mendukung Pengambilan Keputusan Investasi Pada PT. Pan Brothers Tbk. Sekolah Tinggi Ilmu Ekonomi Kesatuan. Bogor. Jurnal Ilmiah Kesatuan. Vol. 14. No. 1. (2012) http://jurnal.stiekesatuan.ac.id/index.php/jik/article/viewFile/282/307. Diakses Maret, 15, 2015. Hal.87-92

Skousen 2001, Akuntansi Keuangan Menengah- Buku Satu. Penerbit Salemba Empat, Jakarta

Warsono, Darmawan dan Ridha 2009, Akuntansi Ternyata Logis dan Mudah.Penerbit Asgard Chapter, Yogyakarta.

Wahjono Imam Sentot 2010, Perilaku Organisasi - Edisi Pertama. Penerbit Graha Ilmu, Yogyakarta.

Wahyudiono Bambang 2014. Mudah Membaca Laporan Keuangan. Penerbit Raih Asa Sukses, Jakarta.

www.bulog.co.id 